\title{
Social costs of icatibant self-administration vs. health professional-administration in the treatment of hereditary angioedema in Spain
}

\author{
Antonio J Blasco ${ }^{1 *}$, Pablo Lázaro ${ }^{1}$, Teresa Caballero ${ }^{2}$ and Mar Guilarte ${ }^{3}$
}

\begin{abstract}
Background: Icatibant is the only subcutaneous treatment for acute Type I and Type II hereditary angioedema with C1-esterase inhibitor deficiency (HAE-C1-INH) licensed for self-administration in Europe.

Aim: To compare the economic impact of two icatibant administration strategies: health professionaladministration only (strategy 1) versus including the patient self-administration option (strategy 2).

Methods: Economic evaluation model based on the building of a decision tree. Both strategies are assumed to have equivalent effectiveness. The payer (Spanish National Health System) and the social perspectives were considered. All relevant cost-generating factors were taken into account. The time horizon was one year. Sources of information included scientific evidence, official data and experts' opinion. A deterministic sensitivity analysis was carried out to quantify the underlying uncertainty in the model.

Results: From the social perspective, which considers both direct (health care costs) and indirect costs (productivity losses), strategy 2 would result into average savings of $€ 121.30$ per acute attack compared to strategy 1. For Spain, this would achieve in an annual savings of $€ 551,371$. The reduction in direct costs accounts for $74 \%$ of the savings and lower indirect costs account for the remaining 26\%. Savings per acute attack may range from $€ 79.50$ to $€ 169.80$; accordingly, the annual savings in Spain may vary between $€ 90,319$ and $€ 2,315,360$.

Conclusion: Costs related to the management of acute HAE attacks with C1 inhibitor deficiency may be substantially reduced through interventions targeting home treatment by training patients to self-administer icatibant.
\end{abstract}

Keywords: $\mathrm{C} 1-\mathrm{INH}$, Hereditary angioedema, Economic evaluation, Icatibant

\section{Background}

Hereditary angioedema with C1-esterase inhibitor deficiency (HAE-C1-INH) is an autosomal dominant hereditary disease caused by deficiency or dysfunction of the protein C1-esterase inhibitor (C1-INH) [1,2]. The decrease in C1-INH activity may increase plasma concentration of bradykinin, the key mediator of HAE-C1-INH symptoms. Patients with this condition experience recurrent episodes of oedema in subcutaneous tissue or submucosa. Areas affected by this swelling include upper respiratory tract, face, limbs, genitals, and digestive tract

\footnotetext{
* Correspondence: ablasco@taiss.com

${ }^{1}$ Advanced Techniques in Health Services Research (TAISS), Madrid, Spain Full list of author information is available at the end of the article
}

[1,2]. Laryngopharyngeal oedema may be life-threatening due to upper respiratory tract obstruction $[3,4]$.

Icatibant acetate (Firazyr ${ }^{\circledR}$, Shire HGT), a selective bradykinin B2 receptor competitive antagonist, is among the therapies available for acute HAE-C1-INH attacks $[5,6]$. Recommended dosage to treat HAE-C1-INH episodes is a $30 \mathrm{mg}$ subcutaneous injection, preferably in the abdomen [7]. A recent clinical study, named "Evaluation of the Safety of Self-Administration with Icatibant (EASSI)", evaluated the safety, tolerability, convenience, and effectiveness of Firazyr ${ }^{\circledR}$ self-administration [8]. Based on the study's favourable results, the European Medicines Agency (EMA) has recently approved Firazyr ${ }^{\circledR}$ selfadministration for appropriately trained patients in the drug's self-administration technique [9]. Icatibant is the 
only subcutaneous treatment for acute Type I and Type II HAE-C1-INH licensed for self-administration in Europe.

Patient's self-administration of icatibant may reduce healthcare costs and may improve the drug's effectiveness due to the accessibility of the treatment. Additionally, by reducing the need of health centres or emergency services visits, the patient would miss fewer hours of work, study, or leisure time.

To our knowledge, there is a lack of evaluation studies comparing icatibant administration methods. This study was designed to fill that gap and compare the economic costs of two strategies to manage acute HAE-C1-INH attacks in Spain. The first strategy assumes that only healthcare professionals administer the drug (health professional-only administration) and the second strategy contemplates that, in addition to visiting a health professional, patients have the option of self-administering the drug (self-administration).

\section{Methods}

\section{Design}

This economic evaluation study was developed by building a deterministic decision tree model with sensitivity analysis. The theoretical model compares the costs of health professional-only administration (strategy 1) vs. the costs of self-administration option (strategy 2). Since the model assumes that both strategies are equally effective $[8,10,11]$, this is a cost-minimization study. Analyses were performed from two different perspectives: The payer (Spanish National Health System) perspective which considers direct costs only; and the social perspective which considers both direct and indirect costs. Indirect costs are defined as those incurred from labour productivity losses (lost working hours). The time horizon is one year.

\section{Model building}

The model was built in two phases: 1) Decision tree structure; and 2) Values assignation (probabilities and possible values for cost variables). For building the decision tree, the sequence of events was established, and the cost-generating variables and the categories for each variable for each of the two strategies were defined (Table 1). Variables were defined as follows: Attack severity: mild (discomfort that does not disrupt regular daily activities); moderate (discomfort that reduces or impacts regular daily activities); and severe (symptoms preventing work or daily activities) [1]. Episode duration is the time between the onset of symptoms and their complete resolution. Length of stay is the time patients spend in a healthcare facility. Labour force participation categories are: Employed, Unpaid household work and Other (unemployed, students, retired or early retirees due to permanent disability, recipients of pensions other than retirement or early retirement, volunteers in social work, charity organizations, and other [12]). Since icatibant is not approved for younger than 18 years, the age category "under 18 " was not considered. The final product was a decision tree structure applicable to $\mathrm{HAE}$ episode management for the two treatment strategies. Figure 1 shows a simplified model of the decision tree. During the second phase, the model content was completed assigning probabilities to each of the variables' categories, and allocating values to the model's cost variables.

\section{Probability assignment}

Probabilities were assigned based on the best available scientific evidence. In some cases, data were not available or were available for other populations and, thus, the experts (TC, MG) deemed them inappropriate for modelling Spanish events. In these cases, the assignment of probabilities was informed by experts' opinions.

Official data sources were used for the age variable (Spain's population as of April 1st, 2011 [13]) and for the labour participation variable (Labour Force Survey, First Quarter, 2011 [12]).

Experts' opinions informed the parameterization of the remaining variables by assigning estimates of average, maximum, and minimum values for each variable. The experts parameterized the variables anonymously in two separate rounds with no interaction during the first round. The mean of these estimates became the synthesis estimators and during the second round the final values were allocated by consensus.

\section{Cost allocation}

The payer's perspective accounts only for direct medical costs (treatment, hospital emergency room visit, primary care emergency room visit, HAE specialist visit, hospital admission, ICU admission, and tracheotomy) and nonmedical costs (transportation).

Because the healthcare system in Spain is governed by the autonomous communities (AC) (political geographic divisions), there are not national prices. Thus, a resource unit cost based on the official AC lists of resource unit costs [14-31] was estimated. This cost was calculated as the average price for healthcare services rendered by the AC Departments of Health. Treatment cost was the pharmaceutical laboratory sale's price (LSP) plus the value added tax (VAT).

Transportation costs were estimated using data from the Centro de Estudios y Experimentación de Obras Públicas (CEDEX) (Center for Public Works Studies and Experimentation) [32]. CEDEX provides estimates of the cost per kilometre of private transportation taking into account the investment, maintenance, vehicle repairs, tires change, insurance policy, motor vehicle tax, gasoline, parking, fines, and tolls. 
Table 1 Variables included in the model

\begin{tabular}{|c|c|c|c|}
\hline \multirow[b]{2}{*}{ Variable } & \multicolumn{3}{|c|}{ Value } \\
\hline & Average & Minimum & Maximum \\
\hline \multicolumn{4}{|l|}{ Age (number of residents) } \\
\hline $18-64$ years & $29,963,795$ & & \\
\hline$\geq 65$ years & $7,914,361$ & & \\
\hline \multicolumn{4}{|l|}{ Work status (\%) } \\
\hline Employed & $59.88 \%$ & & \\
\hline Unpaid household work & $8.78 \%$ & & \\
\hline Other & $31.34 \%$ & & \\
\hline HAE Prevalence per 100,000 persons & 2.00 & 1.00 & 4.00 \\
\hline Number of episodes per year & 6.00 & 3.00 & 9.00 \\
\hline \multicolumn{4}{|l|}{ Severity (\%) } \\
\hline Mild & $35.00 \%$ & & \\
\hline Moderate & $45.00 \%$ & & \\
\hline Severe & $20.00 \%$ & & \\
\hline \multicolumn{4}{|l|}{ Episode duration with strategy 1 (hours) } \\
\hline Mild & 15.00 & 13.00 & 18.00 \\
\hline Moderate & 10.00 & 8.00 & 12.00 \\
\hline Severe & 17.00 & 14.00 & 21.00 \\
\hline \multicolumn{4}{|c|}{ Reduction of episode duration with strategy 2 (\%) } \\
\hline Mild & $50.00 \%$ & & \\
\hline Moderate & $60.00 \%$ & & \\
\hline Severe & $70.00 \%$ & & \\
\hline \multicolumn{4}{|l|}{ Episode duration with strategy 2 (hours) } \\
\hline Mild & 7.50 & 6.50 & 9.00 \\
\hline Moderate & 4.00 & 3.20 & 4.80 \\
\hline Severe & 5.10 & 4.20 & 6.30 \\
\hline \multicolumn{4}{|c|}{ With strategy 1 , a mild episode results in (\%) } \\
\hline Hospital emergency room visit & $2.00 \%$ & $1.00 \%$ & $3.00 \%$ \\
\hline Primary care emergency room visit & $3.00 \%$ & $2.00 \%$ & $4.00 \%$ \\
\hline HAE specialist office visit & $2.00 \%$ & $1.00 \%$ & $3.00 \%$ \\
\hline No emergency visit & $93.00 \%$ & $96.00 \%$ & $90.00 \%$ \\
\hline \multicolumn{4}{|c|}{ With strategy 1, a moderate episode results in (\%) } \\
\hline Hospital emergency room visit & $70.00 \%$ & $60.00 \%$ & $80.00 \%$ \\
\hline Primary care emergency room visit & $5.00 \%$ & $3.00 \%$ & $7.00 \%$ \\
\hline HAE specialist office visit & $10.00 \%$ & $7.00 \%$ & $12.00 \%$ \\
\hline No emergency visit & $15.00 \%$ & $30.00 \%$ & $1.00 \%$ \\
\hline \multicolumn{4}{|c|}{ With strategy 1 , a severe episode results in (\%) } \\
\hline Hospital emergency room visit & $87.00 \%$ & $85.00 \%$ & $89.00 \%$ \\
\hline Primary care emergency room visit & $2.00 \%$ & $1.00 \%$ & $3.00 \%$ \\
\hline HAE specialist office visit & $9.00 \%$ & $6.00 \%$ & $8.00 \%$ \\
\hline No emergency visit & $2.00 \%$ & $8.00 \%$ & $0.00 \%$ \\
\hline \multicolumn{4}{|c|}{ With strategy 2 , a mild episode results in (\%) } \\
\hline Hospital emergency room visit & $0.00 \%$ & $0.00 \%$ & $0.00 \%$ \\
\hline Primary care emergency room visit & $0.00 \%$ & $0.00 \%$ & $0.00 \%$ \\
\hline
\end{tabular}


Table 1 Variables included in the model (Continued)

\begin{tabular}{|c|c|c|c|}
\hline HAE specialist office visit & $0.00 \%$ & $0.00 \%$ & $0.00 \%$ \\
\hline No emergency visit & $100.00 \%$ & $100.00 \%$ & $100.00 \%$ \\
\hline \multicolumn{4}{|c|}{ With strategy 2 , a moderate episode results in (\%) } \\
\hline Hospital emergency room visit & $10.00 \%$ & $7.00 \%$ & $12.00 \%$ \\
\hline Primary care emergency room visit & $1.00 \%$ & $0.00 \%$ & $2.00 \%$ \\
\hline HAE specialist office visit & $3.00 \%$ & $1.00 \%$ & $5.00 \%$ \\
\hline No emergency visit & $86.00 \%$ & $92.00 \%$ & $81.00 \%$ \\
\hline \multicolumn{4}{|c|}{ With strategy 2 , a severe episode results in (\%) } \\
\hline Hospital emergency room visit & $15.00 \%$ & $12.00 \%$ & $18.00 \%$ \\
\hline Primary care emergency room visit & $1.00 \%$ & $0.00 \%$ & $2.00 \%$ \\
\hline HAE specialist office visit & $4.00 \%$ & $2.00 \%$ & $6.00 \%$ \\
\hline No emergency visit & $80.00 \%$ & $86.00 \%$ & $74.00 \%$ \\
\hline \multicolumn{4}{|c|}{ Length of stay in hospital emergency room (hours) } \\
\hline Mild & 4.0 & 3.0 & 6.0 \\
\hline Moderate & 7.0 & 5.0 & 9.0 \\
\hline Severe & 16.0 & 12.0 & 20.0 \\
\hline \multicolumn{4}{|c|}{ Length of stay in primary care emergency room (hours) } \\
\hline Mild & 2.0 & 1.0 & 3.0 \\
\hline Moderate & 4.0 & 3.0 & 5.0 \\
\hline Severe & 6.0 & 4.0 & 8.0 \\
\hline \multicolumn{4}{|c|}{ Length of stay at the HAE specialist (hours) } \\
\hline Mild & 1.5 & 1.0 & 2.0 \\
\hline Moderate & 2.0 & 1.0 & 3.0 \\
\hline Severe & 5.0 & 4.0 & 6.0 \\
\hline \multicolumn{4}{|c|}{ Round trip distance to healthcare facility (Km) } \\
\hline To hospital & 30.00 & 20.00 & 40.00 \\
\hline To primary care centre & 4.00 & 2.00 & 6.00 \\
\hline \multicolumn{4}{|l|}{ Round trip travel time (minutes) } \\
\hline To hospital & 45.00 & 30.00 & 60.00 \\
\hline To primary care centre & 15.00 & 10.00 & 20.00 \\
\hline \multicolumn{4}{|c|}{ Timing of episodes among gainfully employed (\%) } \\
\hline Work hours & $21.92 \%$ & & \\
\hline Non work hours & $78.08 \%$ & & \\
\hline \multicolumn{4}{|c|}{ Timing of episodes among unpaid homemakers (\%) } \\
\hline Work hours & $30.59 \%$ & & \\
\hline Non work hours & $69.41 \%$ & & \\
\hline \multicolumn{4}{|c|}{$\%$ episode duration during which unable to work } \\
\hline Mild & $0.00 \%$ & $0.0 \%$ & $0.0 \%$ \\
\hline Moderate & $40.00 \%$ & $30.0 \%$ & $50.0 \%$ \\
\hline Severe & $80.00 \%$ & $70.0 \%$ & $90.0 \%$ \\
\hline \multicolumn{4}{|c|}{ Probability (\%) patient comes with a caretaker (by age group and episode severity) } \\
\hline 18-64 years/mild & $50.0 \%$ & $40.0 \%$ & $60.0 \%$ \\
\hline 18-64 years/moderate & $60.0 \%$ & $50.0 \%$ & $70.0 \%$ \\
\hline 18-64 years/severe & $95.0 \%$ & $90.0 \%$ & $100.0 \%$ \\
\hline$\geq 65$ years/mild & $70.0 \%$ & $60.0 \%$ & $80.0 \%$ \\
\hline
\end{tabular}


Table 1 Variables included in the model (Continued)

\begin{tabular}{|c|c|c|c|}
\hline$\geq 65$ years/moderate & $80.0 \%$ & $70.0 \%$ & $95.0 \%$ \\
\hline$\geq 65$ years/severe & $95.0 \%$ & $90.0 \%$ & $100.0 \%$ \\
\hline \multicolumn{4}{|c|}{$\%$ of episode duration patient requires caretaker (by age group and episode severity) } \\
\hline 18-64 years/mild & $0.0 \%$ & $0.0 \%$ & $0.0 \%$ \\
\hline 18-64 years/moderate & $20.0 \%$ & $15.0 \%$ & $30.0 \%$ \\
\hline 18-64 years/severe & $70.0 \%$ & $60.0 \%$ & $80.0 \%$ \\
\hline$\geq 65$ years $/$ mild & $0.0 \%$ & $0.0 \%$ & $0.0 \%$ \\
\hline$\geq 65$ years/moderate & $40.0 \%$ & $30.0 \%$ & $50.0 \%$ \\
\hline$\geq 65$ years/severe & $80.0 \%$ & $70.0 \%$ & $90.0 \%$ \\
\hline \multicolumn{4}{|c|}{ Icatibant syringes per episode } \\
\hline Mild & 1.00 & 0.90 & 1.10 \\
\hline Moderate & 1.10 & 1.00 & 1.20 \\
\hline Severe & 1.10 & 1.00 & 1.30 \\
\hline \multicolumn{4}{|c|}{ With strategy 1 , during a severe episode the probability (\%) of: } \\
\hline Death & $0.01 \%$ & $0.005 \%$ & $0.015 \%$ \\
\hline Tracheotomy & $0.20 \%$ & $0.10 \%$ & $0.30 \%$ \\
\hline Hospital admission & $0.40 \%$ & $0.30 \%$ & $0.50 \%$ \\
\hline \multicolumn{4}{|c|}{ Length of admission for severe episode (days): } \\
\hline General ward & 2.00 & 1.00 & 3.00 \\
\hline ICU & 2.00 & 1.00 & 3.00 \\
\hline \multicolumn{4}{|c|}{ With strategy 2 , during a severe episode the probability (\%) of: } \\
\hline Death & $0.0010 \%$ & $0.0005 \%$ & $0.0015 \%$ \\
\hline Tracheotomy & $0.0200 \%$ & $0.0100 \%$ & $0.0300 \%$ \\
\hline Hospital admission & $0.1000 \%$ & $0.0500 \%$ & $0.1500 \%$ \\
\hline
\end{tabular}

Icatibant administration: Strategy $1=$ Health professional-administration only; Strategy $2=$ Self-administration also available.

The social perspective accounts for both direct and indirect costs. Indirect costs are defined as patient's and caretaker's working hours lost per episode plus working hours lost in case of patient's death. Leisure time lost was not included in the calculation. For employed workers, labour cost was estimated using the human capital method, based on the cost of the working hour reported in the Quarterly Survey of Labour Costs during the Fourth Quarter of 2010 [33]. For unpaid work (household work) the substitution cost method was used.

The cost of lost labour due to the patient's death was estimated multiplying the years the patient would no longer contribute to the national wealth (contributing years lost) times the per capita gross domestic product (GDP). The per capita GDP was calculated dividing the national 2009 GDP (last available datum) [34] by the Spanish population count as of July 1st, 2009 [13]. To calculate contributing years lost, it was assumed that, in average, patients under 65 years-old die at 41.5 years of age. For those 65 and over, death occurs half way between 65 and life expectancy at 65 . The amount of contributing years lost is the difference between life expectancy [35] and age at death.
The product of this phase was the final model: a decision tree loaded with the probability values and the costs associated with each path.

\section{Sensitivity analysis}

A sensitivity analysis was performed to evaluate the underlying uncertainty dependent on the variability in the experts' estimators and the resources unit costs. Three scenarios were built under this analysis: base case scenario; most favourable (for strategy 2 vs. strategy 1 ); and least favourable (for strategy 2 vs. strategy 1 ). Unit costs for resources were allowed a potential variability of $\pm 5 \%$.

Base case scenario employs the average unit costs and the average experts' estimators. The most favourable scenario uses the maximum unit costs and maximum experts' estimators, except for the following variables in strategy 2: Facility in which episode is treated, probability of death given a severe episode, probability of tracheotomy given a severe episode, and probability of admission given a severe episode for which the minimum estimators were entered. For the least favourable scenario the minimum unit costs and minimum experts' estimators were considered, except for the variables mentioned above in 


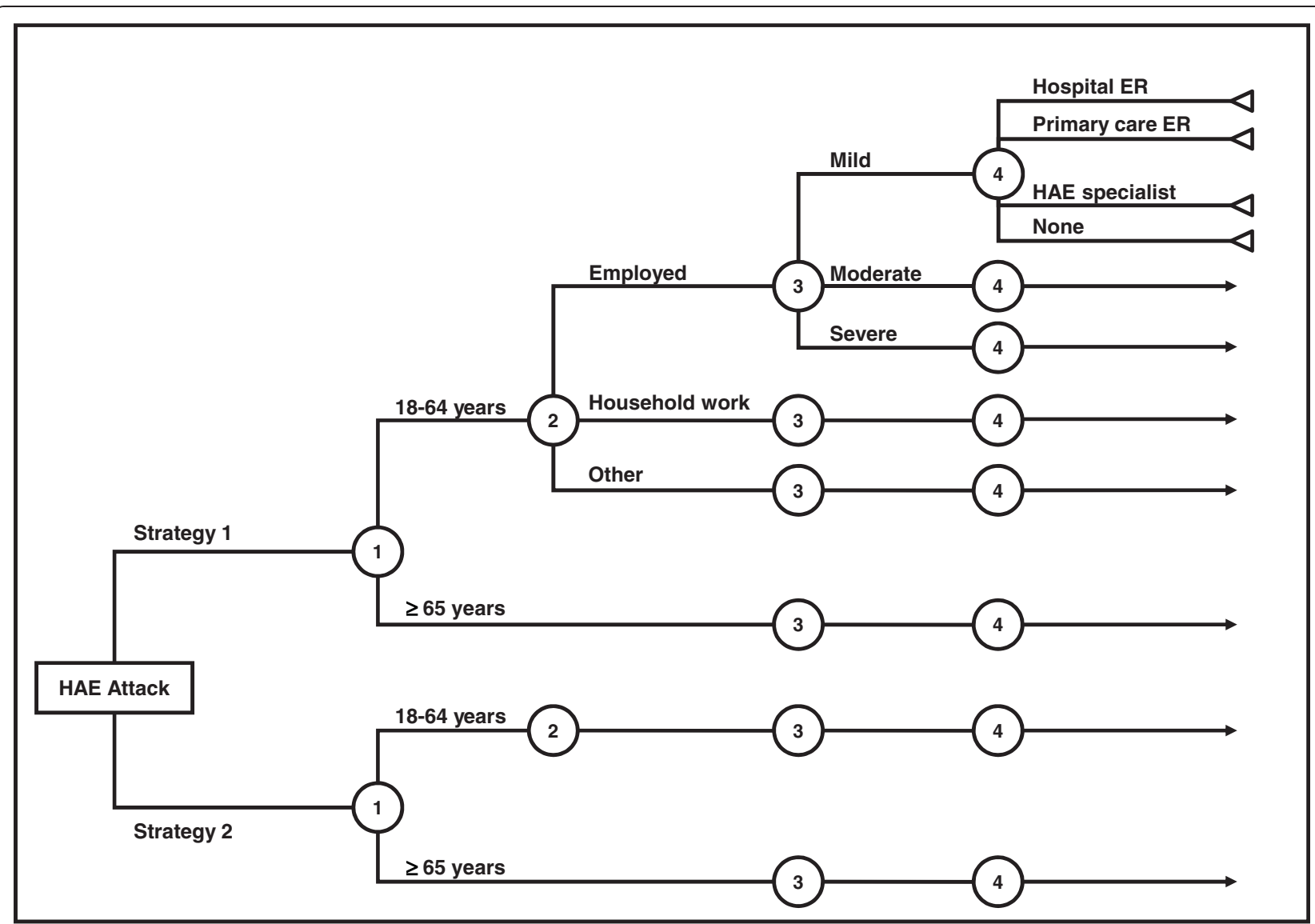

Figure 1 Simplified model of decision tree. Icatibant administration: Strategy $1=$ Health professional-administration only; Strategy $2=$ Selfadministration also available. HAE: Hereditary angioedema. ER: Emergency room.

strategy 2 for which the maximum estimators were entered.

\section{Results}

Table 1 shows the values assigned to the variables in the model. Table 2 shows unit costs of the resources included in the model.

In the base case scenario, HAE-C1-INH prevalence is 2 per 100,000 persons and each patient suffers an average of 6 acute attacks per year. Consequently, it is estimated that in Spain there would be 758 HAE-C1-INH patients experiencing a total of 4,545 acute attacks per year. Using the social perspective, the average cost of managing one of these episodes with strategy 1 (health professional-administration) would be $€ 1,315.14$ versus $€ 1,193.84$ with strategy 2 (self-administration option). This translates into an average savings of $€ 121.30$ (9.2\% cost reduction) per episode with strategy 2 , representing an annual saving of $€ 551,371$ nationwide. A reduction in direct costs would account for $74 \%$ of the savings and a decrease in indirect costs would make up the remaining $26 \%$ of the money saved. With the payer perspective, the average savings per episode would be $€ 89.8$ (7\%), which
Table 2 Unit costs of resources used in 2011

\begin{tabular}{lcc}
\hline Variable & Cost $(\boldsymbol{€})$ & Unit \\
\hline Direct costs & & \\
Medical & & \\
$\quad$ Icatibant & $1,762.80$ & syringe $30 \mathrm{mg}$ \\
Hospital emergency & 169.73 & visit \\
$\quad$ Primary care emergency & 100.76 & visit \\
$\quad$ services & & \\
HAE specialist & 131.67 & visit \\
$\quad$ General ward admission & 443.61 & day \\
ICU admission & $1,115.61$ & day \\
Tracheotomy & 464.66 & tracheotomy \\
\hline Non-medical & & km \\
$\quad$ Transportation & 0.45 & hour \\
\hline Indirect costs & & hour \\
Employee loss labour & 17.27 & death \\
Homemaker loss labour & 10.00 & death \\
Death among & 921,984 & \\
18-64 year-olds & & \\
Death among $\geq 65$ year-olds & 232,446 &
\end{tabular}


Table 3 Cost of managing HAE episodes with icatibant (Euros)

\begin{tabular}{|c|c|c|c|c|c|c|c|}
\hline \multirow[b]{2}{*}{ Variable } & \multicolumn{3}{|c|}{ Per episode } & \multicolumn{3}{|c|}{ Nationwide per year } & \multirow[b]{2}{*}{ Savings (\%) } \\
\hline & Strategy 1 & Strategy 2 & Savings & Strategy 1 & Strategy 2 & Savings & \\
\hline Direct costs & $1,272.42$ & $1,182.62$ & 89.80 & $5,783,612$ & $5,375,455$ & 408,157 & 7.06 \\
\hline Medical & $1,264.71$ & $1,181.31$ & 83.40 & $5,748,578$ & $5,369,480$ & 379,098 & 6.59 \\
\hline Icatibant & $1,164.95$ & $1,164.95$ & 0.00 & $5,295,122$ & $5,295,122$ & 0 & 0.00 \\
\hline Visits* & 97.13 & 16.22 & 80.92 & 441,498 & 73,706 & 367,792 & 83.31 \\
\hline Admissions & 2.44 & 0.12 & 2.32 & 11,113 & 567 & 10,546 & 94.90 \\
\hline Tracheotomy & 0.19 & 0.02 & 0.17 & 845 & 84 & 760 & 90.00 \\
\hline Non-medical & 7.71 & 1.31 & 6.39 & 35,034 & 5,975 & 29,059 & 82.95 \\
\hline Transportation & 7.71 & 1.31 & 6.39 & 35,034 & 5,975 & 29,059 & 82.95 \\
\hline Indirect costs & 42.73 & 11.22 & 31.51 & 194,220 & 51,006 & 143,214 & 73.74 \\
\hline Caretaker & 13.54 & 4.81 & 8.73 & 61,535 & 21,844 & 39,691 & 64.50 \\
\hline Labour loss & 13.63 & 4.86 & 8.77 & 61,967 & 22,090 & 39,877 & 64.35 \\
\hline Death & 15.56 & 1.56 & 14.00 & 70,718 & 7,072 & 63,646 & 90.00 \\
\hline Social cost & $1,315.14$ & $1,193.84$ & 121.30 & $5,977,832$ & $5,426,461$ & 551,371 & 9.22 \\
\hline
\end{tabular}

Strategy $1=$ Health professional-administration only; Strategy $2=$ Self-administration also available.

*Includes visits to hospital emergency rooms, primary care centres emergency rooms, and to HAE specialist offices.

would result into an annual saving of $€ 408,157$ nationwide. The decrease in healthcare services use (emergency services and visits to specialists) accounts for the bulk of the savings (Table 3 ).

The number of episodes and the average treatment cost (with the social perspective), according to patient's age and severity of the attack is showed in Table 4 . The more severe the episode, the greater the savings are. Savings are also greater in patients under 65 than in those 65 and over, due to the greater reduction in indirect costs.

\section{Sensitivity analysis}

In the most favourable scenario for strategy 2, HAE-C1INH prevalence is 4 per 100,000 persons and each patient experiences an average of 9 acute attacks per year.
This would add up to 1,515 patients suffering a total of 13,636 acute attacks per year. Under the social perspective, the average cost of managing an episode would be $€ 1,664.21$ with strategy 1 and $€ 1,494.41$ with strategy 2 . Therefore, strategy 2 (self-administration option) would save an average of $€ 169.80$ (10.2\%) per episode (Table 5) which would translate into an annual saving of $€ 2,315,360$ nationwide. The reduction in direct costs would account for $70 \%$ of the savings and a decrease in indirect costs would explain the remaining $30 \%$ (Table 6). With the payer perspective, the average savings would be $€ 119.21$ (7.5\%) which represent an annual saving of $€ 1,625,616$ nationwide.

In the least favourable scenario for strategy 2, HAEC1-INH prevalence is 1 per 100,000 persons and each patient suffers an average of 3 acute attacks per year.

Table 4 Number of episodes and average cost (Euros) based on the social perspective, according to age group and episode severity

\begin{tabular}{|c|c|c|c|c|c|c|}
\hline \multirow[b]{2}{*}{ Age } & \multirow[b]{2}{*}{ Severity } & \multirow[b]{2}{*}{ Episodes (N) } & \multicolumn{2}{|c|}{ Cost $(€)$} & \multirow[b]{2}{*}{ Savings $(€)$} & \multirow[b]{2}{*}{ Savings (\%) } \\
\hline & & & Strategy 1 & Strategy 2 & & \\
\hline \multirow{4}{*}{$18-64$ years } & Mild & 1,258 & 133.8 & 123.4 & 10.43 & 7.80 \\
\hline & Moderate & 1,618 & $1,826.3$ & $1,681.6$ & 144.76 & 7.93 \\
\hline & Severe & 719 & $2,262.2$ & $1,976.2$ & 285.99 & 12.64 \\
\hline & Total & 3,596 & $1,321.1$ & $1,195.1$ & 125.99 & 9.54 \\
\hline \multirow{4}{*}{$\geq 65$ years } & Mild & 332 & 133.4 & 123.4 & 10.01 & 7.51 \\
\hline & Moderate & 427 & $1,812.3$ & $1,677.7$ & 134.52 & 7.42 \\
\hline & Severe & 190 & $2,151.5$ & $1,953.9$ & 197.59 & 9.18 \\
\hline & Total & 950 & $1,292.5$ & $1,189.0$ & 103.56 & 8.01 \\
\hline TOTAL & & 4,545 & $1,315.1$ & $1,193.8$ & 121.30 & 9.22 \\
\hline
\end{tabular}

Strategy $1=$ Health professional-administration only; Strategy $2=$ Self-administration also available. 
Table 5 Average cost of managing HAE episodes with icatibant (Euros)

\begin{tabular}{|c|c|c|c|c|c|c|c|c|}
\hline \multirow[b]{2}{*}{ Variable } & \multicolumn{4}{|c|}{ Most favourable scenario } & \multicolumn{4}{|c|}{ Least favourable scenario } \\
\hline & Strategy $1(€)$ & Strategy $2(€)$ & Savings $(€)$ & Savings (\%) & Strategy $1(€)$ & Strategy $2(€)$ & Savings $(€)$ & Savings (\%) \\
\hline Direct costs & $1,600.16$ & $1,480.94$ & 119.21 & 7.45 & 986.69 & 923.07 & 63.62 & 6.45 \\
\hline Medical & $1,588.12$ & $1,479.73$ & 108.39 & 6.82 & 982.48 & 922.00 & 60.48 & 6.16 \\
\hline Icatibant & $1,468.59$ & $1,468.59$ & 0.00 & 0.00 & 901.85 & 901.85 & 0.00 & 0.00 \\
\hline Visits* & 114.33 & 11.07 & 103.26 & 90.32 & 79.54 & 20.07 & 59.47 & 74.77 \\
\hline Admissions & 4.91 & 0.07 & 4.84 & 98.60 & 0.82 & 0.05 & 0.77 & 93.78 \\
\hline Tracheotomy & 0.29 & 0.01 & 0.28 & 96.67 & 0.26 & 0.03 & 0.24 & 90.00 \\
\hline Non-medical & 12.03 & 1.21 & 10.82 & 89.95 & 4.21 & 1.08 & 3.14 & 74.47 \\
\hline Transportation & 12.03 & 1.21 & 10.82 & 89.95 & 4.21 & 1.08 & 3.14 & 74.47 \\
\hline Indirect costs & 64.05 & 13.47 & 50.58 & 78.97 & 25.21 & 9.34 & 15.87 & 62.95 \\
\hline Caretaker & 20.56 & 6.47 & 14.09 & 68.53 & 8.62 & 3.49 & 5,14 & 59.55 \\
\hline Labor loss & 18.98 & 6.18 & 12.80 & 67.45 & 9.19 & 3.63 & 5.56 & 60.46 \\
\hline Death & 24.50 & 0.82 & 23.69 & 96.67 & 7.39 & 2.22 & 5.17 & 70.00 \\
\hline Social costs & $1,664.21$ & $1,494.41$ & 169.80 & 10.20 & $1,011.89$ & 932.41 & 79.48 & 7.85 \\
\hline
\end{tabular}

Strategy $1=$ Health professional-administration only; Strategy $2=$ Self-administration also available.

*Includes visits to hospital emergency rooms, primary care centres emergency rooms, and to HAE specialist offices.

Sensitivity analysis.

That is, there would be 379 patients experiencing a total of 1,136 acute attacks per year. Under the social perspective, the average cost of managing an episode would be $€ 1,011.89$ with strategy 1 and $€ 932.41$ with strategy 2 . Thus, strategy 2 yields an average savings of $€ 79.48$ per episode (7.9\%) (Table 5). This leads to an annual saving of $€ 90,319$ nationwide. Direct costs reduction would account for $80 \%$ of the savings and a decrease in indirect costs would explain the remaining 20\% (Table 6). Using the payer perspective, the average saving per episode would be $€ 63.62$ (6.5\%) which would represent an annual saving of $€ 72,289$ nationwide.

Table 7 shows the number of episodes and the average treatment cost (with the social perspective) according to patient's age and severity of the attack, for the most and least favourable scenarios.

In summary, the cost comparison between strategy 2 and 1 , shows that with the social perspective, savings per episode would be of $€ 121.3$ that could range from $€ 79.5$ to $€ 169.8$. This equals to save the $9.2 \%$ of the costs,

Table 6 Nationwide annual cost of managing HAE episodes with icatibant (Euros)

\begin{tabular}{|c|c|c|c|c|c|c|c|c|}
\hline \multirow[b]{2}{*}{ Variable } & \multicolumn{4}{|c|}{ Most favourable scenario } & \multicolumn{4}{|c|}{ Least favourable scenario } \\
\hline & Strategy $1(€)$ & Strategy $2(€)$ & Savings $(€)$ & Savings (\%) & Strategy $1(€)$ & Strategy $2(€)$ & Savings $(€)$ & Savings (\%) \\
\hline Direct costs & $21,819,956$ & $20,194,340$ & $1,625,616$ & 7.45 & $1,121,218$ & $1,048,929$ & 72,289 & 6.45 \\
\hline Medical & $21,655,858$ & $20,177,846$ & $1,478,012$ & 6.82 & $1,116,431$ & $1,047,707$ & 68,723 & 6.16 \\
\hline Icatibant & $20,025,875$ & $20,025,875$ & 0 & 0.00 & $1,024,811$ & $1,024,811$ & 0 & 0.00 \\
\hline Visits* & $1,559,016$ & 150,900 & $1,408,116$ & 90.32 & 90,390 & 22,808 & 67,581 & 74.77 \\
\hline Admissions & 66,974 & 938 & 66,037 & 98.60 & 929 & 58 & 871 & 93.78 \\
\hline Tracheotomy & 3,992 & 133 & 3,859 & 96.67 & 301 & 30 & 271 & 90.00 \\
\hline Non-medical & 164,099 & 16,494 & 147,604 & 89.95 & 4,787 & 1,222 & 3,565 & 74.47 \\
\hline Transportation & 164,099 & 16,494 & 147,604 & 89.95 & 4,787 & 1,222 & 3,565 & 74.47 \\
\hline Indirect costs & 873,371 & 183,627 & 689,743 & 78.97 & 28,643 & 10,613 & 18,030 & 62.95 \\
\hline Caretaker & 280,398 & 88,246 & 192,152 & 68.53 & 9,800 & 3,964 & 5,837 & 59.55 \\
\hline Labor loss & 258,830 & 84,243 & 174,587 & 67.45 & 10,445 & 4,130 & 6,315 & 60.46 \\
\hline Death & 334,142 & 11,138 & 323,004 & 96.67 & 8,398 & 2,519 & 5,878 & 70.00 \\
\hline Social costs & $22,693,327$ & $20,377,967$ & $2,315,360$ & 10.20 & $1,149,861$ & $1,059,542$ & 90,319 & 7.85 \\
\hline
\end{tabular}

Strategy 1 = Health professional-administration only; Strategy $2=$ Self-administration also available.

*Includes visits to hospital emergency rooms, primary care centres emergency rooms, and to HAE specialist offices.

Sensitivity analysis. 
Table 7 Number of episodes and average cost (Euros) with the social perspective, according to age group and episode severity

\begin{tabular}{|c|c|c|c|c|c|c|c|c|c|c|c|}
\hline \multirow[b]{2}{*}{ Age } & \multirow[b]{2}{*}{ Severity } & \multicolumn{5}{|c|}{ Most favourable scenario } & \multicolumn{5}{|c|}{ Least favourable scenario } \\
\hline & & $\begin{array}{r}\text { Episodes } \\
\text { (N) }\end{array}$ & $\begin{array}{r}\text { Strategy } 1 \\
(€)\end{array}$ & $\begin{array}{r}\text { Strategy } 2 \\
(€)\end{array}$ & $\begin{array}{r}\text { Savings } \\
(€)\end{array}$ & $\begin{array}{r}\text { Savings } \\
(\%)\end{array}$ & $\begin{array}{r}\text { Episodes } \\
\text { (N) }\end{array}$ & $\begin{array}{r}\text { Strategy } 1 \\
(€)\end{array}$ & $\begin{array}{r}\text { Strategy } 2 \\
(€)\end{array}$ & $\begin{array}{r}\text { Savings } \\
(€)\end{array}$ & $\begin{array}{r}\text { Savings } \\
(\%)\end{array}$ \\
\hline \multirow{4}{*}{$\begin{array}{l}18-64 \\
\text { years }\end{array}$} & Mild & 3,775 & 210.7 & 193.9 & 16.8 & 7.98 & 315 & 68.7 & 63.5 & 5.2 & 7.59 \\
\hline & Moderate & 4,854 & $2,325.1$ & $2,122.8$ & 202.3 & 8.70 & 405 & $1,365.6$ & $1,269.4$ & 96.2 & 7.04 \\
\hline & Severe & 2,157 & $2,764.7$ & $2,363.6$ & 401.1 & 14.51 & 180 & $1,883.9$ & $1,700.6$ & 183.3 & 9.73 \\
\hline & Total & 10,787 & $1,673.0$ & $1,495.9$ & 177.2 & 10.59 & 899 & $1,015.3$ & 933.6 & 81.8 & 8.05 \\
\hline \multirow{4}{*}{$\begin{array}{l}\geq 65 \\
\text { years }\end{array}$} & Mild & 997 & 209.8 & 193.9 & 15.9 & 7.58 & 83 & 68.5 & 63.5 & 5.1 & 7.40 \\
\hline & Moderate & 1,282 & $2,304.9$ & $2,117.6$ & 187.3 & 8.13 & 107 & $1,357.2$ & $1,266.7$ & 90.6 & 6.67 \\
\hline & Severe & 570 & $2,601.0$ & $2,340.8$ & 260.3 & 10.01 & 47 & $1,820.4$ & $1,678.9$ & 141.6 & 7.78 \\
\hline & Total & 2,849 & $1,630.9$ & $1,489.0$ & 141.9 & 8.70 & 237 & 998.8 & 928.0 & 70.8 & 7.09 \\
\hline TOTAL & & 13,636 & $1,664.2$ & $1,494.4$ & 169.8 & 10.20 & 1,136 & $1,011.9$ & 932.4 & 79.5 & 7.85 \\
\hline
\end{tabular}

Strategy $1=$ Health professional-administration only; Strategy $2=$ Self-administration also available

Sensitivity Analysis.

which could range between $7.9 \%$ and $10.2 \%$. Annual cost reduction in Spain would be of $€ 551,371$ ranging from $€ 90,319$ to $€ 2,315,360$.

With the payer perspective, savings per episode would be $€ 89.80$ that could range from $€ 63.60$ to $€ 119.20$. This equals to a savings of $7 \%$ which could range from $6.5 \%$ to $7.5 \%$. Annual cost reduction in Spain would be $€ 408,157$ ranging between $€ 72,289$ and $€ 1,625,616$.

\section{Discussion}

According to this study's findings, the possibility of patients self-administering icatibant to control acute HAEC1-INH attacks brings about substantial reduction in both direct and indirect costs, resulting in savings for the National Health System and for the society as a whole. To our knowledge and based on our literature search, this is the first study to date that has evaluated the economic costs involved in self-administration.

One of the strengths of the current study is that it comprises all relevant variables impacting the cost of managing acute HAE-C1-INH attacks, including the indirect costs related to patients' and caretakers' loss of labour hours. Further, these indirect costs also account for the years of life lost due to the unfortunate premature deaths which, though uncommon, do occur in this patient population.

The main study limitation is the scant scientific evidence available on the study variables. In the absence of scientific evidence, the next best alternative to fill this information gap is the experts' opinion. Although the panel consisted of only two experts, they are both renowned opinion leaders on this disease with ample experience in the management of HAE-C1-INH in Spain. Another possible limitation of the study is that the costs of training patients to self-administer the treatment were not taken into account. However, these costs would be irrelevant, since, in practice, the patients receive the training in the regular visits to the specialist. Finally, the model assumes neither underuse nor overuse of icatibant in the two compared strategies. However, it would be possible that in some settings, overuse or underuse may occur.

The alternative of self-administration of icatibant opens the possibility of early treatment of acute attacks at the first symptoms which may decrease attack severity [36,37]. For instance, potentially severe attacks may turn into mild attacks thanks to early treatment which is likely to lead to even greater savings than those estimated in this study.

In addition, the unpredictability of the timing, frequency, and severity of acute HAE-C1-INH attacks generate a substantial amount of stress in patients. Having the means to control an acute attack quickly and effectively may reduce that stress. This piece of mind compounds another unquantifiable benefit such as the patient's quality of life improvement derived from the reduction of previous restrictions in daily activities as well as work and school absenteeism $[37,38]$.

\section{Conclusions}

Both the clinical aspects of HAE-C1-INH and, now, the economic aspects revealed in this study, strongly suggest the need for targeted interventions. These interventions would address home availability of the treatment specific to acute attacks as proposed by national and international consensus [38-41] and HAE-C1-INH patients' training on the proper technique of icatibant selfadministration.

\section{Abbreviations}

AC: Autonomous communities; C1-INH: C1-esterase inhibitor; CEDEX: Centro de Estudios y Experimentación de Obras Públicas (Center for Public Works Studies and Experimentation); GDP: Gross domestic product; HAE-C1-

$\mathrm{INH}$ : Angioedema with C1-esterase inhibitor deficiency. 


\section{Competing interests}

This study was supported by Shire Pharmaceuticals Ibérica. TC has received sponsorship for educational purposes, has been paid for providing consultancy services, and has taken part in clinical trials sponsored by Jerini AG/Shire, CSL Behring, Dyax Corp, Pharming NV, and ViroPharma Incorporated. MC has received sponsorship for educational purposes and has been paid for providing consultancy services from CSL Behring, Jerini AG/ Shire, and ViroPharma Incorporated; and has taken part in clinical trials sponsored by Jerini AG/Shire, Pharming NV and ViroPharma Incorporated. AJB and PL work as researchers in TAISS; TAISS has received funding from Shire for developing the project.

\section{Authors' contributions}

AJB did substantial contributions to the project conception and design, participated in the data acquisition and in the analysis and interpretation of data, prepared the draft of the article and approved the final version. PL did substantial contributions to conception and design, participated in the acquisition of data and in the analysis and interpretation of data, revised the manuscript critically for important intellectual content and approved the final version. TC did substantial contributions to conception and design, participated in the acquisition of data and in the interpretation of data, revised the manuscript critically for important intellectual content and approved the final version. MG did substantial contributions to conception and design, participated in the acquisition of data and in the interpretation of data, revised the manuscript critically for important intellectual content and approved the final version. All authors read and approved the final manuscript.

\section{Author details}

${ }^{1}$ Advanced Techniques in Health Services Research (TAISS), Madrid, Spain. ${ }^{2}$ Allergy Service, Hospital La Paz Health Research Center (IdiPaz), Biomedical Research Network on Rare Diseases-U754 (CIBERER), Madrid, Spain. ${ }^{3}$ Allergy Section, Department of Internal Medicine, Hospital Universitario Vall d’Hebron, Universitat Autònoma de Barcelona, Barcelona, Spain.

\section{Received: 5 September 2012 Accepted: 1 February 2013}

Published: 12 February 2013

\section{References}

1. Agostoni A, Aygoren-Pursun E, Binkley KE, Blanch A, Bork K, Bouillet L, Bucher C, Castaldo AJ, Cicardi M, Davis AE, De Carolis C, Drouet C, Duponchel C, Farkas H, Fáy K, Fekete B, Fischer B, Fontana L, Füst G, Giacomelli R, Gröner A, Hack CE, Harmat G, Jakenfelds J, Juers M, Kalmár L, Kaposi PN, Karádi I, Kitzinger A, Kollár T, et al: Hereditary and acquired angioedema: problems and progress: proceedings of the third $\mathrm{C}$ esterase inhibitor deficiency workshop and beyond. J Allergy Clin Immunol 2004, 114(Suppl 3):S51-S131.

2. Caballero T, Baeza M, Cabañas R, Campos A, Cimbollek S, Gomez-Traseira C, González-Quevedo T, Guilarte M, Jurado-Palomo GJ, Larco Jl, López-Serrano MC, López-Trascasa M, Marcos C, Muñoz-Caro JM, Pedrosa M, Prior N, Rubio M, Sala-Cunill A, Spanish Study Group on Bradykinin-Induced Angioedema: Consensus statement on the diagnosis, management, and treatment of angioedema mediated by bradykinin. Part I. classification, epidemiology, pathophysiology, genetics, clinical symptoms, and diagnosis. J Invest Allergol Clin Immunol 2011, 21:333-347.

3. Bork K, Siedlecki K, Bosch S, Schopf RE, Kreuz W: Asphyxiation by laryngeal edema in patients with hereditary angioedema. Mayo Clin Proc 2000, 75:349-354

4. Bork K, Barnstedt SE: Laryngeal edema and death from asphyxiation after tooth extraction in four patients with hereditary angioedema. J Am Dent Assoc 2003, 134:1088-1094

5. Bork K, Frank J, Grundt B, Schlattmann P, Nussberger J, Kreuz W: Treatment of acute edema attacks in hereditary angioedema with a bradykinin receptor2 antagonist (icatibant). J Allergy Clin Immunol 2007, 119:1497-1503.

6. Cicardi M, Banerji A, Bracho F, Malbrán A, Rosenkranz B, Riedl M, Bork K, Lumry W, Aberer W, Bier H, Bas M, Greve J, Hoffmann TK, Farkas H, Reshef A, Ritchie B, Yang W, Grabbe J, Kivity S, Kreuz W, Levy RJ, Luger T, Obtulowicz K, Schmid-Grendelmeier P, Bull C, Sitkauskiene B, Smith WB, Toubi E, Werner $S$, Anné $S$, et al: Icatibant, a new bradykinin-receptor antagonist, in hereditary angioedema. N Engl J Med 2010, 363:532-541.
7. European Medicines Agency: Firazyr. Annex 1. Summary of products characteristics. 2011. http://www.ema.europa.eu/docs/es_ES/ document_library/EPAR__Product_Information/human/000899/ WC500022966.pdf, accessed on June $9^{\text {th }}$.

8. Aberer W, Toubi E: Safety, Tolerability and Efficacy of Self-Administered Icatibant for Acute Attacks of Hereditary Angioedema (P337). Boston, Massachusetts (USA): The American College of Allergy, Asthma and Immunology. 2011 Annual Scientific Meeting; 2011.

9. European Medicines Agency: Firazyr: Procedural steps taken and scientific information after the authorisation. EMA CHMP/367939/2011. 2011. http:// www.ema.europa.eu/docs/en_GB/document_library/EPAR__Procedural_steps_taken_and_scientific_information_after_authorisation/ human/000899/WC500022971.pdf, accessed on June $9^{\text {th }}$.

10. Boccon-Gibod I, Bouillet L, On behalf of the EASSI Study Investigators: Safety and efficacy of icatibant self-administration for acute hereditary angioedema. Clin Exp Immunol 2012, 168:303-307.

11. Floccard B, Hautin E, Bouillet L, Coppere B, Allaouchiche B: An evidence-based review of the potential role of icatibant in the treatment of acute attacks in hereditary angioedema type I and II. Core Evidence 2012, 7:105-114.

12. National Institute of Statistics: Economically Active Population Survey. 2011. http://www.ine.es/jaxi/menu.do?type=pcaxis\&path=/t22/ e308_mnu\&file=inebase $\& N=\& L=0$, accessed on June $9^{\text {th }}$.

13. National Institute of Statistics: Population figures and Demographic Censuses. 2011. http://www.ine.es/inebmenu/mnu_cifraspob.htm, accessed on June $9^{\text {th }}$.

14. ORDER of 14 October 2005 , which are priced public health services provided by centres under the Andalusian Public Health System. Official Gazette of the Autonomous Community of Andalusia 2005, 210.

15. ORDER of the Minister of Health and Consumer, of 11 September 2008 , amending the Order of the Minister for Health and Consumers of 22 December 2006 laying down the public prices to be applied by health centres in the public network of the Balearic Islands by the provision of health services when there are third parties required to pay or users without the right to health care of Social Security. Official Gazette of the Balearic Islands 2008, 131

16. LAW 12/2009 of 23 December on Fiscal, Administrative and Financial Management, and Organization of the Valencia Government. Official Gazette of the Autonomous Community of Valencia 2009, 6175.

17. ORDER $629 / 2009$ of 31 August, fixing public prices for the provision of services and health activities of the network of centres of the Community of Madrid. Official Gazette of the Community of Madrid 2009, 215.

18. ORDER of 17 May 2007, of the Ministry of Health, which creates public prices applied by the Health Service of Murcia, for the provision of health services and the supply of blood products. Official Gazette of the Region of Murcia 2007, 129.

19. RESOLUTION, $1687 / 2010$ of 24 August, of the Managing Director of Navarra Health Service, which amends Resolution 882/2010 of 3 May, of the Managing Director of Navarra Health Service for updating the fees by the provision of services in centres and care establishments of Navarra Health Service. Official Gazette of Navarre 2010, 115.

20. AGREEMENT of 13 December 2007, the Board of Directors of the Public Entity Osakidetza Basque Health Service, for approving the tariffs for the provision of health and educational services to third parties required to pay to during 2008. Official Gazette of Basque Country 2008, 12.

21. RESOLUTION of 16 June 2009 , of the National Institute of Health Management, on price review to be applied by the health centres in the Autonomous Cities of Ceuta and Melilla by the medical care in the cases whose amount have to be claimed to third parties required to pay or users without the right to health care of Social Security, as well as services provided by the National Dosimetry Centre and reproduction of documents in the library of the managing body. Government Gazette 2009, 150.

22. RESOLUTION of 2 April 2004, of the Directorate Management of Aragon Health Service on revision of tariffs to apply by the provision of health services to third parties required to pay or to users without the right to health care of Social Security in the Community Aragon. Official Gazette of Aragon 2004, 46

23. DECREE $34 / 2006$ of 19 April, by which set prices by the provision of services and activities of health by centres under the Health Service of the Principality of Asturias. Official Gazette of the Principality of Asturias 2006, 105

24. DECREE $81 / 2009$ of 16 June, establishing the public prices of health services provided by the Canary Islands Health Service and fixing their amount. Official Gazette of the Canary Islands 2009, 123. 
25. ORDER SAN/8/2007 of 4 April, which fixing the amounts of the public prices of health services provided by the Cantabrian Health Service. Official Gazette of Cantabria 2008, 74.

26. RESOLUTION of 6 April 2010, the Directorate Management, about prices to apply by their health centres to third parties required to pay or users without the right to health care [2010/6830]. Official Gazette of Castilla-La Mancha 2010, 79

27. DECREE $25 / 2010$ of 17 June, updating of public prices are by acts of care and health services provided by the Regional Health Management of Castile and Leon. Official Gazette of Castile and Leon 2010, 119

28. RESOLUTION SLT/383/2009 of 21 January on the review of public fees for health services provided by the Catalan Health Institute. Official Gazette of Government of Catalonia 2009, 5325

29. DECREE $21 / 2009$ of 13 February, changing the amounts of public prices for health services from the Extremadura Health Service established in Decree 272/2005 of 27 December, which down and regulate public prices for health services from the Extremadura Health Service. Official Gazette of Extremadura 2009, 34.

30. DECREE $160 / 2010$ of 23 September, establishing fees for health services provided in the centres under the Galician Health Service and public health foundations. Official Gazette of Galicia 2010, 188.

31. RESOLUTION No. 143 of 4 May 2010, of the Minister of Health by providing for the publication of the charges for health services provided to individuals in the centres of the Rioja Health Service. Official Gazette of the Rioja 2010, 57.

32. Ministry of Promotion, Center for Public Works Studies and Experimentation: Table of cost per kilometre of travel by car. 2011. http://www.cedex.es/ castellano/cedex-transporte/documentos.htm, accessed on June $9^{\text {th }}$.

33. National Institute of Statistics: Quarterly Labour Cost Survey. 2011. http:// www.ine.es/jaxi/menu.do?type=pcaxis\&path=/t22/p187\&file=inebase\&N=\&L, accessed on June $9^{\text {th }}$.

34. National Institute of Statistics: Spanish National Accounts. Base 2000. Update the accounting series 2006-2009. 2011. http://www.ine.es/jaxi/menu.do? type $=$ pcaxis\&path $=\% 2 \mathrm{Ft} 35 \% 2 \mathrm{Fp} 008 \&$ file $=$ inebase $\& \mathrm{~L}=0$, accessed on June $9^{\text {th }}$

35. National Institute of Statistics: Basic Demographic Indicators. 2011. http://www. ine.es/jaxi/menu.do?type=pcaxis\&path =\%2Ft20\%2Fp318\&file=inebase\&L=0, accessed on June $9^{\text {th }}$

36. Maurer M, Aberer W, Bouillet L, Caballero T, Fabient V, Kanny G, Kaplan A, Longhurst H, Zanichelli A, on behalf of IOS Investigators: Hereditary Angioedema Attacks Resolve Faster and are Shorter After Early Icatibant Treatment. Plos One 2013, 8(2):E53773. doi:10.1371/journal.pone.0053773.

37. Bygum A, Andersen KE, Mikkelsen CS: Self-administration of intravenous C1-inhibitor therapy for hereditary angioedema and associated quality of life benefits. Eur J Dermatol 2009, 19:147-151.

38. Longhurst $\mathrm{HJ}$, Farkas $\mathrm{H}$, Craig T, Aygören-Pürsün E, Bethune C, Bjorkander J, Bork K, Bouillet L, Boysen H, Bygum A, Caballero T, Cicardi M, Dempster J, Gompels M, Gooi J, Grigoriadou S, Huffer U, Kreuz W, Levi MM, Long J, Martinez-Saguer I, Raguet M, Reshef A, Bowen T, Zuraw B: HAE international home therapy consensus document. Allergy Asthma Clin Immunol 2010, 6:22.

39. Bowen T, Cicardi M, Farkas H, Bork K, Longhurst HJ, Zuraw B, AygoerenPürsün E, Craig T, Binkley K, Hebert J, Ritchie B, Bouillet L, Betschel S, Cogar D, Dean J, Devaraj R, Hamed A, Kamra P, Keith PK, Lacuesta G, Leith E, Lyons H, Mace S, Mako B, Neurath D, Poon MC, Rivard GE, Schellenberg R, Rowan $D$, Rowe $A$, et al: 2010 International consensus algorithm for the diagnosis, therapy and management of hereditary angioedema. Allergy Asthma Clin Immunol 2010, 6:24.

40. Caballero T, Baeza M, Cabañas R, Campos A, Cimbollek S, Gomez-Traseira C, González-Quevedo T, Guilarte M, Jurado-Palomo GJ, Larco Jl, López-Serrano MC, López-Trascasa M, Marcos C, Muñoz-Caro JM, Pedrosa M, Prior N, Rubio M, Sala-Cunill A, Spanish Study Group on Bradykinin-Induced Angioedema: Consensus Statement on the Diagnosis, Management And Treatment of Angioedema Mediated by Bradykinin. Part II. Treatment, Follow-Up, and Special Situations. J Investig Allergol Clin Immunol 2011, 21:422-441.

41. Cicardi M, Bork K, Caballero T, Craig T, Li H, Longhurst H, Reshef A, Zuraw B, HAWK (Hereditary Angioedema International Working Group: Evidencebased recommendations for the therapeutic management of angioedema due to hereditary C1-Inhibitor deficiency. Consensus report of an International Working Group. Allergy 2012, 129:308-320.

doi:10.1186/2191-1991-3-2

Cite this article as: Blasco et al: Social costs of icatibant selfadministration vs. health professional-administration in the treatment of hereditary angioedema in Spain. Health Economics Review 2013 3:2.

\section{Submit your manuscript to a SpringerOpen ${ }^{\mathcal{D}}$ journal and benefit from:}

- Convenient online submission

- Rigorous peer review

- Immediate publication on acceptance

- Open access: articles freely available online

- High visibility within the field

- Retaining the copyright to your article

Submit your next manuscript at $>$ springeropen.com 